\title{
Three new species of Macrobiotus (Eutardigrada, Macrobiotidae, tenuis-group) from Tien Shan (Kirghizia) and Spitsbergen
}

\author{
Denis V. TUMANOV
}

Laboratory of Freshwater and Experimental Hydrobiology, Zoological Institute, Russian Academy of Sciences, St. Petersburg, 199034, Russia

e-mail: tardigrada@zin.ru

\begin{abstract}
Illustrated descriptions of Macrobiotus danilovi sp. n., Macrobiotus tenuiformis sp. n. from Tien Shan (Kirghizia) and Macrobiotus voronkovi $s p$. $n$. from Spitsbergen are given. These new species belong to the tenuis-group of the genus Macrobiotus. Members of the tenius-group have claws with a particularly long and thin common tract with a prominent frontal appendage at the base. Macrobiotus danilovi and M. tenuiformis differ from all known species of this group in the structure of their buccal armature. Macrobiotus voronkovi differs from all known species of the tenuis-group in its combination of features in adult animals and in the egg shell.
\end{abstract}

Key words: Tardigrada, Macrobiotus danilovi sp. n., Macrobiotus tenuiformis sp. n., Macrobiotus voronkovi $s p . n$.

\section{INTRODUCTION}

A group of Macrobiotus species similar to Macrobiotus tenuis Binda and Pilato, 1972 (tenuis-group) was established as the tenuis-group by Maucci $(1987 \mathrm{a}, \mathrm{b})$ on the basis of a set of characters in the adult animals. Later key characters and composition of this group were revised (Tumanov 2005) and a key structure, the tenuistype claw, was defined. Macrobiotus ariekammensis Weglarska, 1965 together with the similar species Macrobiotus kirghizicus Tumanov, 2005 were excluded from tenuis-group because their claw structure did not conform to that of the tenuis-type claw. Features of the tenuis-claw type are as follows: (a) slender claws with main and secondary branches well differentiated; (b) long thin common tract (secondary branch diverging at about half of the claw length); (c) distal part of basal portion typical of genus Macrobiotus; and (d) the stalk, connecting the claw base with the lunules, forming a prominent frontal appendage on the claw base (Binda \& Pilato 1972; Tumanov 2005).

Today the tenuis-group consists of eight Macrobiotus species: Macrobiotus bondavallii Manicardi, 1989; Macrobiotus higginsi Maucci, 1987; Macrobiotus hyperonyx Maucci, 1982; Macrobiotus hystricogenitus Maucci, 1976; Macrobiotus kozharai Biserov, 1999; Macrobiotus mongolicus Maucci, 1987; Macrobiotus willardi Pilato, 1977; and M. tenuis.

During my work with tardigrade material from Kirghizia and Spitsbergen, I found three new species of Macrobiotus belonging to the tenuis-group. Their descriptions are given below.

\section{METHODS}

Tardigrades were extracted from dried moss samples. Specimens were fixed with acetic acid and then mounted in Faure fluid.

For comparison, the following specimens were examined: M. ariekammensis (Spitzbergen population from collection of H. Dastych, University of Hamburg, Germany); M. bondavallii (collection of R. Bertolani, University of Modena and Reggio Emilia, Italy); $M$. higginsi, M. hyperonyx, M. hystricogenitus, and $M$. mongolicus (collection of W. Maucci, Museum of Natural History of Verona, Italy); M. tenuis (collection of Binda and Pilato, University of Catania, Italy); and $M$. willardi (Zoological Institute of the Russian Academy of Sciences collection (№ 96-03-16)). All material was examined using phase contrast microscopy.

The $p t$ index is the ratio of the length of a structure to buccal tube length expressed as a percentage (Pilato 1981). Body length was measured from the anterior body margin to the end of the body, excluding the hind legs. Buccal tube length was measured from the level of the dorsal transverse ridges to the base of the tube (including terminal apophyses but excluding pharyngeal apophyses). Buccal tube width was measured as an outer width at the level of the stylet support's insertion point. Claw lengths were measured from the base of the claw to the top of the main branch (including accessory points but excluding lunules). In the description of claw structure, terms are described according to Guidetti \& Bertolani (2001). In descriptions of Macrobiotus danilovi sp. n. and Macrobiotus voronkovi sp. n., para- 
type measurements are given after the holotype measurements in square brackets (when available).

Holotypes and paratypes are preserved at the Zoological Institute of the Russian Academy of Sciences, St. Petersburg, Russia.

\section{RESULTS}

\subsection{Macrobiotus danilovi sp. n. (Figs 1 and 2)}

Holotype: Slide number 190(9) (sex indeterminate). Collected by Dr. I.G. Danilov, 6.06.1998, Kirghizia, Osh Area.

Additional material: One paratype specimen (slide number 190(12)) and one embryonate egg (slide number 190(11)).

Type locality: Kirghizia, Osh Area, Karakuljin District, vicinity of Kylodjun village, near 2000 m a.s.l., moss on a stone.

Etymology: This species is dedicated to Dr. I.G. Danilov, who kindly collected the material in Kirghizia.

\subsubsection{Description}

Body is $571.9 \mu \mathrm{m}$ in length [412.3 $\mu \mathrm{m}]$, plump, colourless, and without eyes (Fig. 1a). The cuticle is smooth with scarcely visible, small areas of granulation on the ventral side. These areas are similar to those described by Maucci (1973) in M. tenuis. Distribution of granulation areas is as follows: (a) one oval area between legs I, II and III; (b) transverse rows of three areas between first three pairs of legs; (c) two rows of three areas between III and IV pairs of legs; and (d) one pair of tiny areas laterally to anus (Fig. 2a). All legs with dot-like sculpture better developed on legs IV (Figs 1d, 1e and 2d). Mouth opening surrounded with scarcely visible buccal lamellae. Dorsal buccal armature consists of a caudal arc, bearing two large separate granules (Figs 1c and 2b). Ventral buccal armature is not visible. Buccal tube length is $55.5 \mu \mathrm{m}[40.0 \mu \mathrm{m}]$ with external diameter $5.2 \mu \mathrm{m}[3.7 \mu \mathrm{m}]$ in width (Figs $1 \mathrm{~b}$ and $2 \mathrm{~b}$ ). The $p t$ value of external diameter is 9.4 in the holotype [9.3 in the paratype]). Pt index for the insertion point of stylet supports is 77.3 [76.9]. Ventral strengthening bar relatively long (about $37.0 \mu \mathrm{m}$ ) and exceeding half of the length of buccal tube. The buccal tube terminates in well developed apophyses. Pharyngeal bulb suboval, containing two macroplacoids (first with well developed constriction, longer than second) and elongate microplacoids. The first macroplacoid is $11.1 \mu \mathrm{m}$ [8.1 $\mu \mathrm{m}]$ in length, the second $7.4 \mu \mathrm{m}[4.4 \mu \mathrm{m}]$, and microplacoid is $3.2 \mu \mathrm{m}[2.4 \mu \mathrm{m}]$. The $p t$ of first macroplacoid is 20.0 [20.4]), the second, 13.3 [11.1], and the microplacoid, 5.7 [5.9]. Macroplacoid row length is $20.7 \mu \mathrm{m}$ [14.8 $\mu \mathrm{m}$ ] and the $p t$ is 37.3 [37.0]. The placoid row length is $24.4 \mu \mathrm{m}[17.0 \mu \mathrm{m}]$ and the $p t$ is 44.0 [42.6].

Claws of tenuis-type, large, with well developed accessory points arising far from distal end of the main branch (Figs 1d, 1e, 2c and 2d). The claws of the first pair of legs are $14.1 \mu \mathrm{m}$ in length $[10.0 \mu \mathrm{m}], 16.3 \mu \mathrm{m}$ $[10.4 \mu \mathrm{m}]$ on the third pair, and $19.2 \mu \mathrm{m}[11.1 \mu \mathrm{m}]$ on the fourth pair. The $p t$ of claws of the first pair of legs is 25.3 [25.0], 29.3 [25.9] on the third pair, and 34.7 [27.8] on the fourth pair.

All claws have large lunules, especially those of the fourth pair. Lunules of claws on fourth legs have distinct teeth; lunules of legs I-III with slightly wavy edges. Dimensions of the lunules on claws of the hind legs are $11.8 \mu \mathrm{m} \times 5.2 \mu \mathrm{m}$ in the holotype. Legs I-III with two indistinct medially fused elliptical zones of thickened cuticle below claw bases.

Spherical ornamented eggs, laid free and have small conical processes (Figs 1f, 1g, 2e and 2f). About 30 processes are around circumference of egg. Processes have well developed, roundish reticulation. Processes are clearly divided into the hollow basal part and in the apical part. Apical parts of the processes are clearly septate and often bent downward. Processes' bases have small protuberances. Egg shell between processes with poorly developed, irregular granulation. Dimensions of a single egg are $108 \mu \mathrm{m} \times 88 \mu \mathrm{m}$ (without processes). Processes are from $12.0 \mu \mathrm{m}$ to $13.5 \mu \mathrm{m}$ in length with basal diameter from $8.0 \mu \mathrm{m}$ to $8.5 \mu \mathrm{m}$ in diameter. The distance between processes is from $1.0 \mu \mathrm{m}$ to $3.0 \mu \mathrm{m}$.

\subsubsection{Remarks}

Macrobiotus danilovi sp. n. could be easily distinguished from all known species of tenuis-group in having the dorsal armature consisting of a dorsal arc with paired granules instead of transverse ridges. A similar type of buccal armature is present in M. kirghizicus, but the new species has different claw morphology and different structure of the egg shell.

Egg shell morphology of the new species is most similar to that of M. mongolicus and M. kozharai. The species differ in the length of the shell processes, which is the greatest in M. mongolicus $(15.0-17.0 \mu \mathrm{m})$, less in M. danilovi (12.0-13.5 $\mu \mathrm{m})$ and the least in M. kozharai (5.0-9.0 $\mu \mathrm{m})$. In addition, the buccal armature of both $M$. mongolicus and M. kozharai has dorsal transverse ridges, whereas in $M$. danilovi only a dorsal arc with paired granules is present.

\subsection{Macrobiotus tenuiformis sp. n. (Figs 3 and 4, Tab. 1)}

Holotype: Slide number 197(11) (sex indeterminate). Collected by Dr. A.V. Barabanov 17.08.1998, Kirghizia, Chui Area.

Paratypes: Slides number 195(8, 21), 196(13), 197(12, 13, 16), 198(8) from the same locality of the holotype.

Type locality: Kirghizia, Chui Area, northern slope of Kirghizian ridge, Turakaiyn canyon, vicinity of Turakaiyn village, near $2000 \mathrm{~m}$ a.s.1., moss from soil. Thirteen adults and juveniles and 8 eggs (one with embryo) were found. 


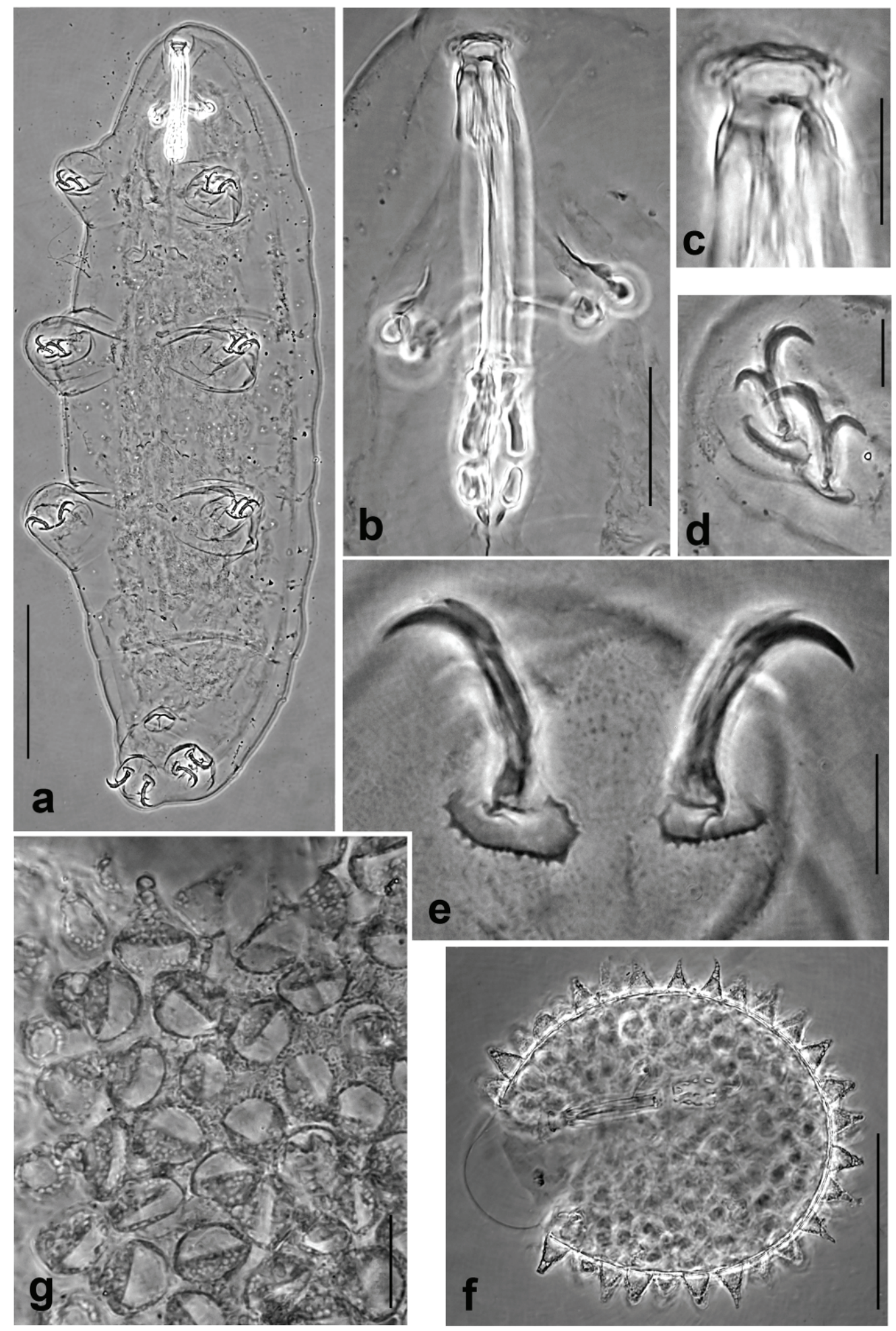

Fig. 1. Macrobiotus danilovi sp. n. a: Habitus. b: Bucco-pharyngeal apparatus. c: Dorsal view of the buccal armature. d: Claws of the second pair of legs. e: Claws of the hind pair of legs. f: General appearance of the egg shell. g: Detail of the egg shell surface. $\mathrm{a}-\mathrm{e}$ : holotype, a-f: phase contrast. Scale bars: $\mathrm{a}=100 \mu \mathrm{m}, \mathrm{b}=25 \mu \mathrm{m}, \mathrm{c}, \mathrm{d}, \mathrm{e}, \mathrm{g}=10 \mu \mathrm{m}, \mathrm{f}=50 \mu \mathrm{m}$. 


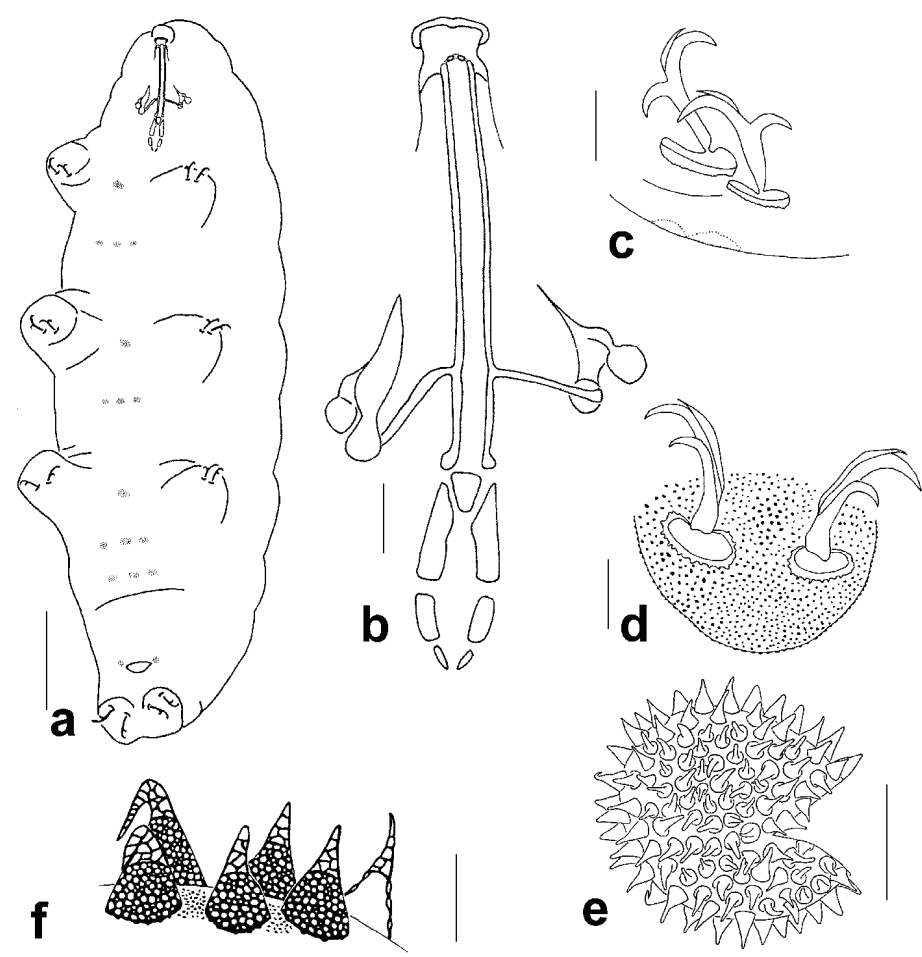

Fig. 2. Macrobiotus danilovi sp. n. a: Habitus (granulated areas are shown schematically). b: Dorsal view of the bucco-pharyngeal apparatus. c: Claws of the second pair of legs. d: Claws of the hind pair of legs. e: General shape of the egg. f: Detail of the egg shell surface. $\mathrm{a}-\mathrm{d}$ : holotype. Scale bars: $\mathrm{a}=100 \mu \mathrm{m}, \mathrm{b}, \mathrm{c}, \mathrm{d}, \mathrm{f}=10 \mu \mathrm{m}, \mathrm{e}=50 \mu \mathrm{m}$.

Tab. 1. Morphometric data for Macrobiotus tenuiformis sp. $\mathrm{n} .(\mathrm{n}=7)$. $\mathrm{Ss}=$ distance from cephalic end of buccal tube to insertion point of stylet supports; S.E.= Standard Error.

\begin{tabular}{|c|c|c|c|c|c|c|c|c|}
\hline & \multicolumn{2}{|c|}{ Holotype } & \multicolumn{2}{|c|}{ Smallest specimen } & \multicolumn{2}{|c|}{ Largest specimen } & \multicolumn{2}{|c|}{ Length } \\
\hline & $\mu \mathrm{m}$ & $p t$ & $\mu \mathrm{m}$ & $p t$ & $\mu \mathrm{m}$ & $p t$ & mean & (S.E.) \\
\hline Body length & 884.5 & & 665.0 & & 917.7 & & 785.7 & $(41.00)$ \\
\hline Buccal tube length & 63.6 & & 52.5 & & 61.4 & & 59.4 & $(1.63)$ \\
\hline Ss & 47.4 & 74.4 & 40.7 & 77.5 & 47.4 & 77.1 & 44.9 & $(1.21)$ \\
\hline Outer buccal tube width & 7.8 & 12.2 & 6.3 & 14.5 & 8.9 & 14.5 & 7.7 & $(0.38)$ \\
\hline Placoid row length & 32.6 & 51.2 & 27.4 & 52.1 & 36.3 & 59.0 & 31.9 & $(1.01)$ \\
\hline Macroplacoid row length & 30.3 & 47.7 & 22.9 & 43.7 & 32.6 & 53.0 & 28.2 & (1.13) \\
\hline First macroplacoid length & 17.0 & 26.7 & 13.7 & 26.1 & 19.2 & 31.3 & 16.3 & $(0.74)$ \\
\hline Second macroplacoid length & 8.9 & 14.0 & 7.6 & 14.5 & 10.7 & 17.5 & 9.1 & $(0.36)$ \\
\hline Microplacoid length & 3.0 & 4.7 & 3.7 & 7.0 & 3.0 & 4.8 & 3.4 & $(0.22)$ \\
\hline External claw length, leg I & 22.2 & 34.9 & 17.8 & 33.8 & 21.5 & 34.9 & 19.9 & $(0.78)$ \\
\hline External claw length, leg III & 11.1 & 2.0 & 18.1 & 34.5 & 22.2 & 36.1 & 20.8 & $(1.17)$ \\
\hline External claw length, leg IV & - & - & 20.0 & 38.0 & 22.9 & 37.3 & 23.0 & $(1.04)$ \\
\hline
\end{tabular}

Etymology: The name tenuiformis indicates that the new species is very similar to $M$. tenuis in both adult and egg shell morphology.

\subsubsection{Description}

Body is long, plump, and colorless. Table 1 reports the dimensions and pt value of the main structure for holotype and adult paratypes. Some specimens have small, granular eye spots (Figs 3a and 4a). Cuticle is smooth, with small areas of granulation on the ventral side only. Distribution of these areas is the same as for Macrobiotus danilovi sp. n. Large specimens have similar granulated areas on dorsal and lateral sides of the body. Legs with dot-like sculpture, scarcely visible in legs I-III and well developed in hind legs (Figs 3f, 4d and $4 \mathrm{e}$ ). Mouth opening surrounded with barely visible buccal lamellae. Dorsal buccal armature caudally with one large medial triangle crest pointed backwards, without points and teeth (Figs 3c, 3d, 4b and 4c). Ventral buccal armature is not visible. Ventral strengthening bar is relatively long ( $35.5 \mu \mathrm{m}$ in the holotype) and exceeds half of the length of the buccal tube. Buccal tube terminates in well developed apophyses. Pharyngeal bulb is suboval, contains two macroplacoids (the first with well developed constriction and longer than the second), and an elongate microplacoid (Figs $3 \mathrm{~b}$ and $4 \mathrm{~b}$ ). Slanting cuticular bars are present between apophyses and first macroplacoid. 

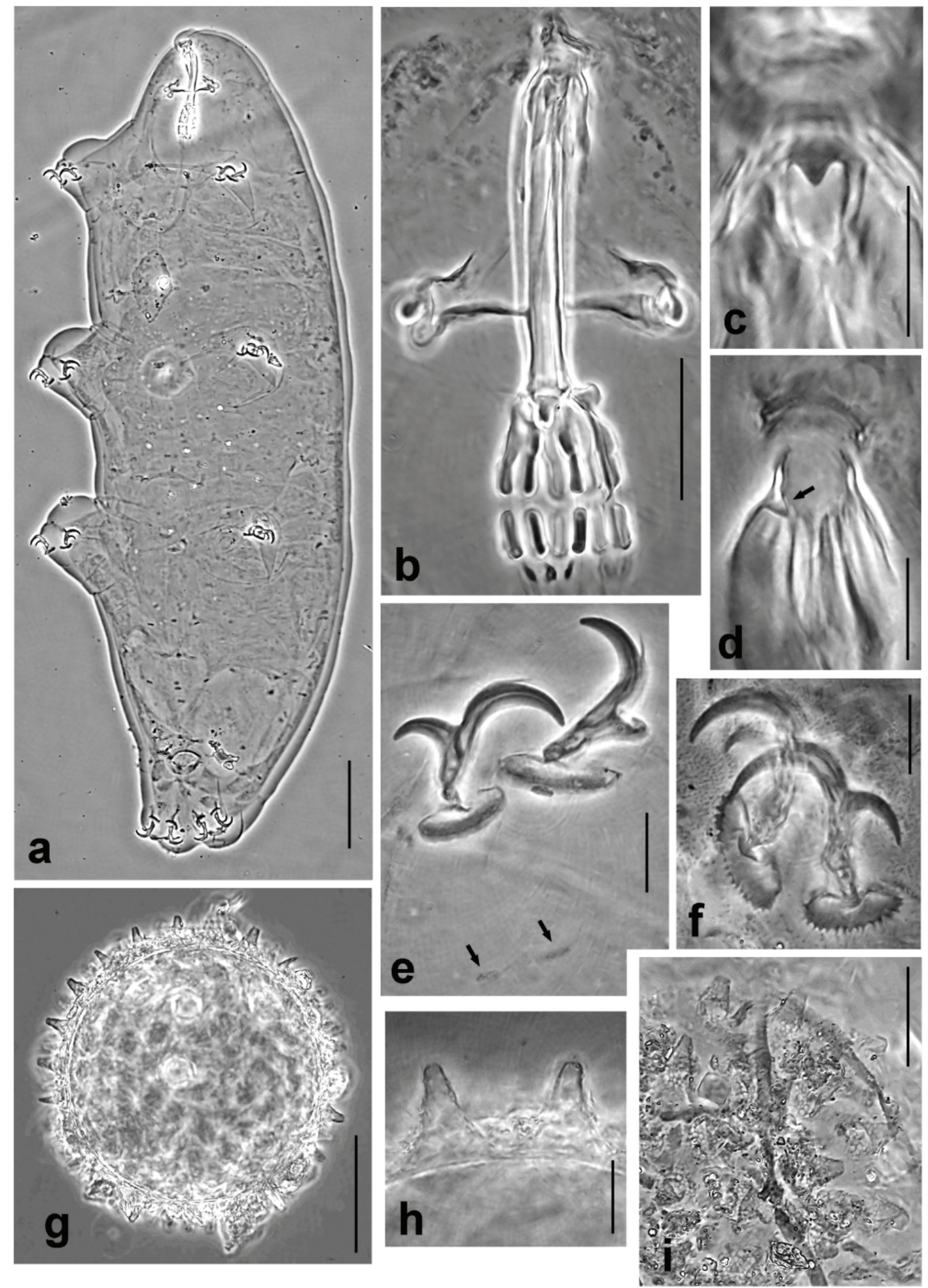

Fig. 3. Macrobiotus tenuiformis sp. n. a: Habitus. b: Bucco-pharyngeal apparatus. c: Dorsal view of the buccal armature. d: Lateral view of the buccal armature. e: Claws of the first pair of legs; arrows indicate the cuticular thickenings). f: Claws of the hind pair of legs. g: General appearance of the egg shell. h: Egg processes. i: Detail of the egg shell surface. c - holotype, a, b, d-f - paratypes, ai: phase contrast.

Scale bars: $\mathrm{a}=100 \mu \mathrm{m}, \mathrm{b}=25 \mu \mathrm{m}, \mathrm{c}, \mathrm{d}, \mathrm{e}, \mathrm{f}, \mathrm{h}=10 \mu \mathrm{m}, \mathrm{g}=50 \mu \mathrm{m}, \mathrm{i}=20 \mu \mathrm{m}$. 


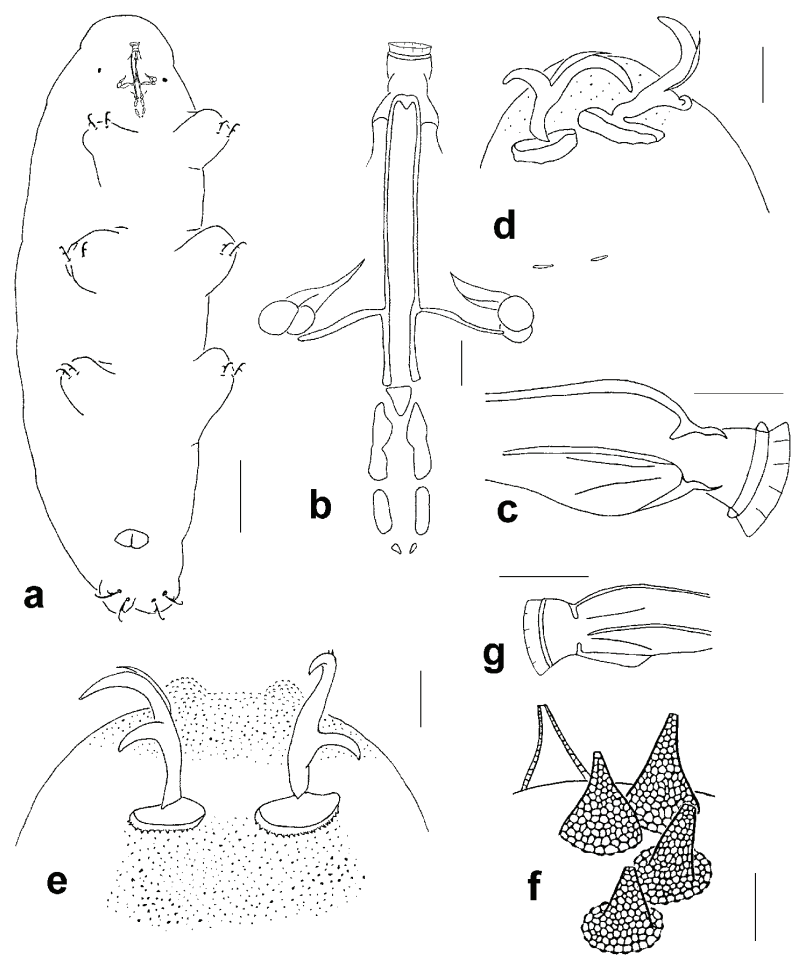

Fig. 4. Macrobiotus tenuiformis sp. n. a: Habitus. b: Dorsal view of the bucco-pharyngeal apparatus. c: Lateral view of the buccal armature. d: Claws of the first pair of legs. e: Claws of the hind pair of legs. f: Detail of the egg shell surface. g: Lateral view of the buccal armature of Macrobiotus tenuis (drawn from a specimen of Pilato \& Binda collection). b - holotype, a, c, d, e - paratypes, a-j: phase contrast. Scale bars: $\mathrm{a}=100 \mu \mathrm{m}, \mathrm{b}-\mathrm{g}=10 \mu \mathrm{m}$.

Claws of tenuis-type, large, with developed accessory points arise far from distal end of the main branch (Figs 3e, 3f, 4d and 4e). All claws with large lunules, especially on legs IV $(17.0$ x $5.2 \mu \mathrm{m}$ in holotype $)$. Lunules of legs IV have distinct teeth, lunules of legs IIII with slightly wavy edges. Legs I-III have scarcely visible paired areas of thickened cuticle below claw bases.

Spherical ornamented eggs, laid free (Figs 3g, 3h, 3i, and $4 \mathrm{f}$ ). Egg processes in form of truncated cones. Processes have well-developed polygonal or roundish reticulation. Egg shell between processes poorly visible because covered with debris. Dimensions of eggs (without processes) are 110.0-112.0 $\mu \mathrm{m}$. Processes are 15.0$15.5 \mu \mathrm{m}$ in length, with basal diameter from $8.9 \mu \mathrm{m}$ to $11.1 \mu \mathrm{m}$. Distance between processes is 3.0-10.0 $\mu \mathrm{m}$.

\subsubsection{Remarks}

Within the tenuis-group the new species is most similar to $M$. tenuis in both adult and egg shell morphology. Macrobiotus tenuiformis sp. n. differs from $M$. tenuis in the following characters: (a) single large dorsal triangular crest in the buccal armature (Fig. 4c) instead of typical complex of dorsal and ventral transverse ridges as present in M. tenuis (Fig. $4 \mathrm{~g}$ ); (b) secondary claw branches are connected to the claws less than half of the claw length while in $M$. tenuis the common portion of the claw is longer than the primary branch; (c) accessory points of the claws in $M$. tenuiformis are welldeveloped and easy to see even in new-born animals, while in $M$. tenuis they are scarcely visible; and (d) adult specimens of $M$. tenuiformis (body length 665.0$917.0 \mu \mathrm{m}$ ) are distinctly longer than M. tenuis (up to $640.0 \mu \mathrm{m}$ ). Eggs of M. tenuiformis are larger (egg diameter 110.0-112.0 $\mu \mathrm{m}$ ) than eggs of M. tenuis (about $85.0 \mu \mathrm{m})$. Egg processes are also larger in $M$. tenuiformis (basal diameter 8.9-11.1 $\mu \mathrm{m}$ and length about $15.0 \mu \mathrm{m}$ ) than in M. tenuis (basal diameter 7.4-8.9 $\mu \mathrm{m}$ and length of 6.7-7.4 $\mu \mathrm{m}$ ), and have a narrower apical part (apex diameter 1.5-3.0 $\mu \mathrm{m}$ in M. tenuiformis and 2.6-3.7 $\mu \mathrm{m}$ in M. tenuis).

Macrobiotus tenuiformis could be easily distinguished from all other species of the tenuis-group in having a single large dorsal triangular crest in the buccal armature and egg processes in form of a truncate cone. A similar type of buccal armature is present in $M$. ariekammensis but this species does not belong to the tenuis-group due the claw morphology. The new species also differs from $M$. ariekammensis in having different egg morphology.

\subsection{Macrobiotus voronkovi sp. n. (Figs 5 and 6)}

Holotype: Slide number 205(1) (sex indeterminate). Collected by Dr. A. Voronkov, 15.09.1996, Spitsbergen.

Paratype: Slide number 205(2) from the same locality. 

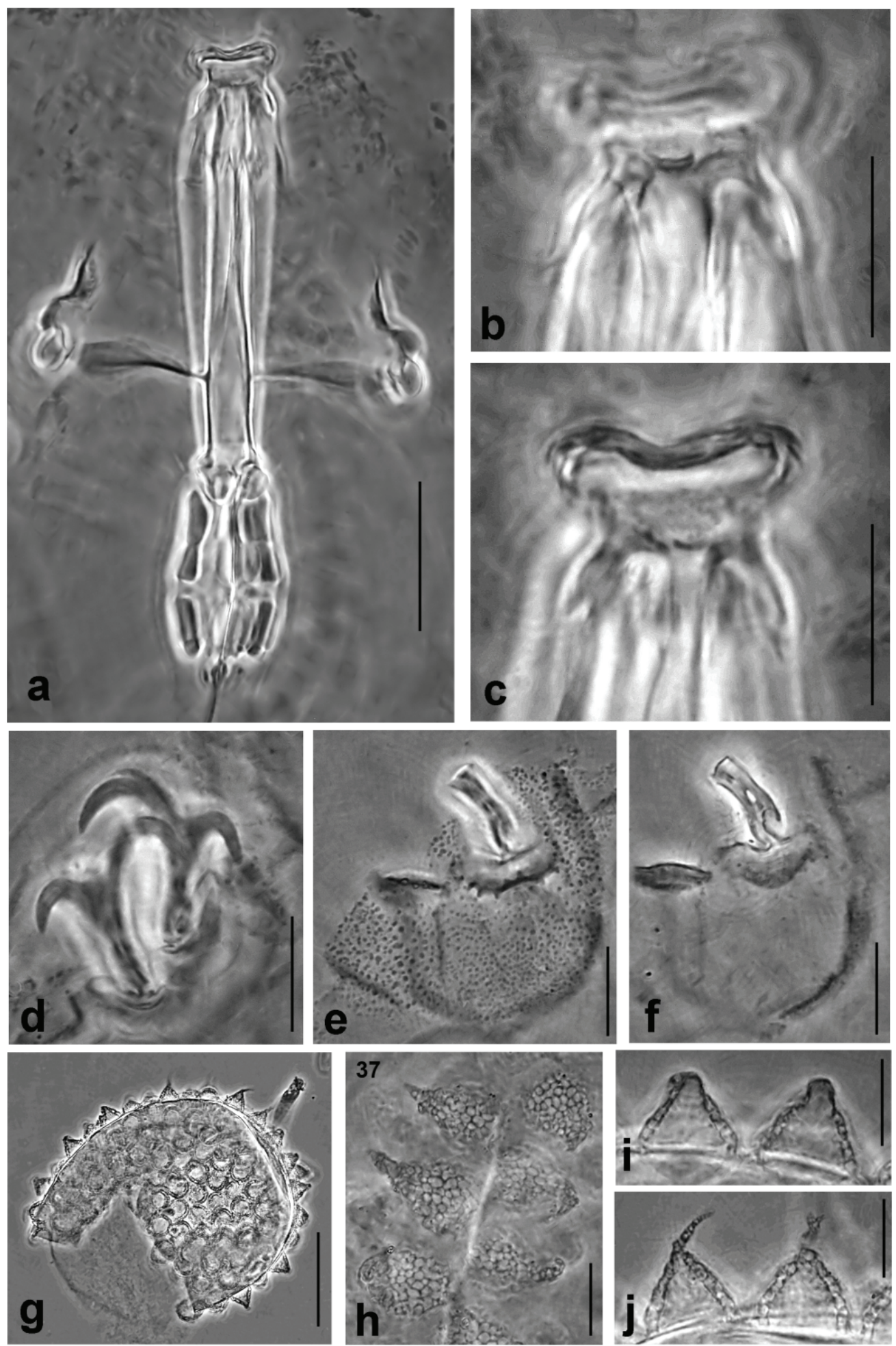

Fig. 5. Macrobiotus voronkovi sp. n. a: Bucco-pharyngeal apparatus. b: Dorsal view of the buccal armature. c: Ventral view of the buccal armature. d: Claws of the third pair of legs. e-f: Basal part of the claw of the hind pair of legs, focused in different levels to show the connection between claw and lunules. $\mathbf{g}$ : General appearance of the egg shell. $\mathbf{h}-\mathbf{j}$ : Egg processes. $\mathrm{d}-\mathrm{f}$ - holotype, $\mathrm{a}-\mathrm{c}-$ paratype, phase contrast. Scale bars: $\mathrm{a}=25 \mu \mathrm{m}, \mathrm{b}-\mathrm{f}, \mathrm{h}-\mathrm{j}=10 \mu \mathrm{m}, \mathrm{g}=50 \mu \mathrm{m}$. 


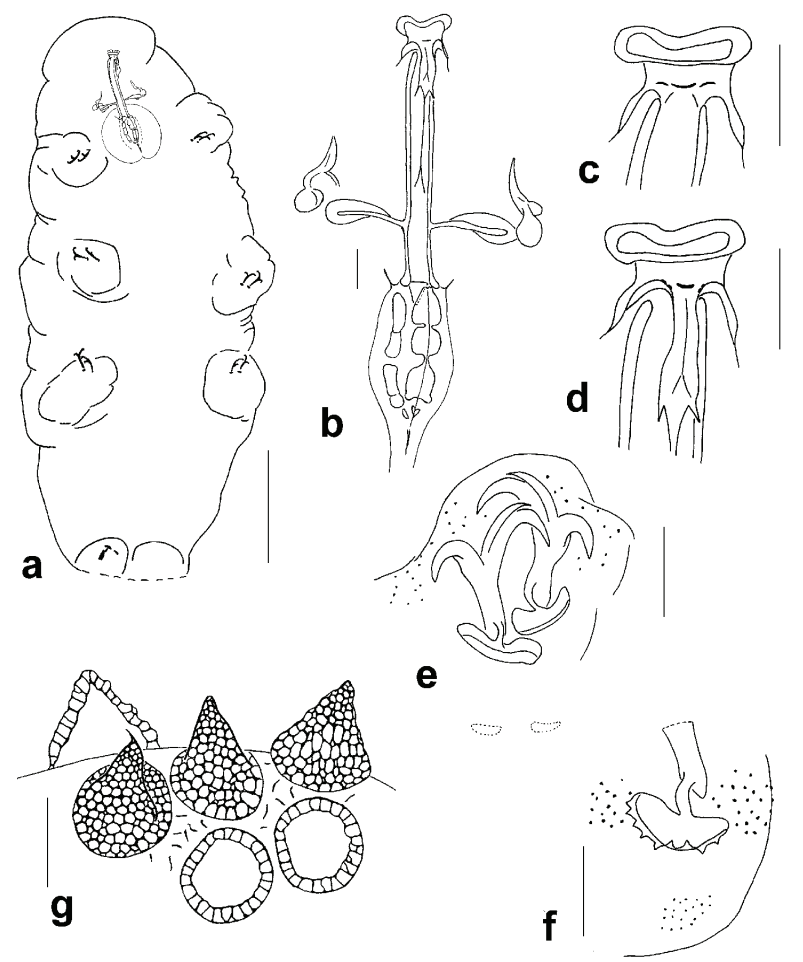

Fig. 6. Macrobiotus voronkovi sp. n. a: Habitus. b: Bucco-pharyngeal apparatus. c: Dorsal view of the buccal armature. d: Ventral view of the buccal armature. e: Claws of the third pair of legs. f: Basal part of the claw of the hind pair of legs. $\mathbf{g}$ : Detail of the egg shell surface. $\mathrm{a}, \mathrm{e}, \mathrm{f}$ - holotype, $\mathrm{b}-\mathrm{d}$ - paratype. Scale bars: $\mathrm{a}=100 \mu \mathrm{m}, \mathrm{b}-\mathrm{g}=10 \mu \mathrm{m}$.

Type locality: Spitsbergen, Konigsfjorden, NyAlesund, small island, moss from soil. Two adults and 5 eggs were found.

Etymology: This species is dedicated to my friend Dr. A. Voronkov, who kindly collected the material for me in Spitsbergen.

\subsubsection{Description}

Body is $532 \mu \mathrm{m}$ in length (holotype), plump, colourless and without eyes (Fig. 6a). Cuticle is smooth, with scarcely visible small areas of granulation. Distribution of these areas is the same as for Macrobiotus danilovi sp. n. and M. tenuiformis sp. n. Similar granulated areas are present on dorsal and lateral surfaces. All legs with dot-like sculpture better developed on legs IV (Figs 5d, 5e, 6e and 6f). Mouth opening is surrounded by scarcely visible buccal lamellae. Dorsal buccal armature consists of three transverse ridges (medial ridge arched with the convexity turned backwards and very thin lateral ridges; Figs $5 \mathrm{~b}$ and $6 \mathrm{c}$ ). Ventral buccal armature consists of a single medial ridge arched with the convexity turned backwards and a pair of lateral ridges fragmented into granules (Figs $5 \mathrm{c}$ and $6 \mathrm{~d}$ ). Buccal tube length is $60.7 \mu \mathrm{m}$ [63.6 $\mu \mathrm{m}]$ and its external diameter is $6.7 \mu \mathrm{m}[7.4 \mu \mathrm{m}]$ in width,. The $p t$ of the external diameter is 11.0 [11.6]. The $p t$ index for the insertion point of stylet supports is 74.4 [76.7]. Ventral strengthening bar is relatively long (about $36.0 \mu \mathrm{m}$ ) and exceeds half of the length of the buccal tube. Buccal tube terminates in well developed apophyses. Pharyngeal bulb suboval, containing two macroplacoids (first with well developed constriction, longer than second) and elongate microplacoids (Figs 5a and 6b) The first macroplacoid is $14.1 \mu \mathrm{m}$ in length [16.3 $\mu \mathrm{m}]$, the second $8.1 \mu \mathrm{m}[14.1 \mu \mathrm{m}]$, and microplacoid is $2.2 \mu \mathrm{m}$ [3.3 $\mu \mathrm{m}]$. The $p t$ of first macroplacoid is 23.2 [25.6]; the second macroplacoid $p t$ is 13.4 [22.1]; and the microplacoid $p t$ is 3.7 [5.2]. Macroplacoid row length is $22.2 \mu \mathrm{m}[28.1 \mu \mathrm{m}]$ and placoid row length is $25.2 \mu \mathrm{m}$ [32.2 $\mu \mathrm{m}]$. The $p t$ of macroplacoid row length is 36.6 [44.2] and the pt of placoid row length is 41.5 [50.6]. Slanting cuticular bars are present between pharyngeal apophyses and first macroplacoid.

Claws of tenuis-type, large, with well developed accessory points arise far from distal end of the main branch (Figs 5d and 6e). Claws of the first pair of legs are $14.8 \mu \mathrm{m}$ in length $[17.0 \mu \mathrm{m}]$ and the third pair are $17.8 \mu \mathrm{m}$. The $p t$ of claws of the first pair of legs is 24.4 [26.7] and 29.3 for the third pair.

Unfortunately, both specimens found have a damaged caudal part, so the length of the claws of hind legs is unknown (Figs 5e, 5f and 6f). All claws have large lunules, especially those of the fourth pair. Lunules of claws of hind legs have distinct teeth; lunules of legs IIII are smooth. Dimensions of lunules on claws of legs IV of the holotype are $12.6 \mu \mathrm{m} \times 4.4 \mu \mathrm{m}$. Legs I-III have two barely visible elliptical zones of thickened cuticle below claw bases. 
Spherical ornamented eggs, laid free, and with small conical processes (Figs 5g, 5h, 5i, 5j and 6g). Processes have blunt or attenuate apices. On the circumference of egg are 20-22 processes with well developed, roundishpolygonal reticulation. Egg shell between processes with a system of poorly developed short irregular ridges. Egg dimensions are $118.3 \mu \mathrm{m} \times 126.8 \mu \mathrm{m}$ (without processes). The processes are from $9.6 \mu \mathrm{m}$ to 14.8 $\mu \mathrm{m}$ in length with basal diameter from $10.4 \mu \mathrm{m}$ to 14.1 $\mu \mathrm{m}$.

\subsubsection{Remarks}

Macrobiotus voronkovi sp. $\mathrm{n}$. is most similar to $M$. danilovi, M. kozharai and M. mongolicus in the details of the egg shell structure. It differs from $M$. kozharai in absence of eyes, in having a single transverse ridge in the ventral buccal armature and in having longer egg processes (length of processes 9.6-14.8 $\mu \mathrm{m}$ in $M$. voronkovi sp. n. and 5.0-9.0 $\mu \mathrm{m}$ in $M$. kozharai). It differs from $M$. mongolicus in having a single transverse ridge in the ventral buccal armature, slightly more caudal position of the insertion point of the stylet supports (mean pt is 74.4-76.7 in M. voronkovi sp. n. and 73.2 in M. mongolicus) and in having shorter egg processes (9.6-14.8 $\mu \mathrm{m}$ in $M$. voronkovi $\mathrm{sp}$. $\mathrm{n}$. and $15.0-17.0 \mu \mathrm{m}$ in M. mongolicus). It differs from $M$. danilovi sp. n. in having buccal armature with transverse ridges and in having egg processes not divided into a hollow basal and in septate apical parts.

Macrobiotus voronkovi sp. $\mathrm{n}$. is also similar to $M$. bondavallii in details of buccal armature (system of three dorsal and three ventral transverse ridges, with latero-ventral ridges broken into several granules). New species differs from $M$. bondavallii in having shorter egg processes (length of processes is 9.6-14.8 $\mu \mathrm{m}$ in $M$. voronkovi $\mathrm{sp} . \mathrm{n}$. and $20.0-24.0 \mu \mathrm{m}$ in $M$. bondavallii) and high number of shell processes (on the circumference 20-22 in $M$. voronkovi sp. n. and 12-15 in M. bondavallii).

\section{CONCLUSION}

Description of three new species supports the integrity of the revised tenuis-group of the genus Macrobio- tus. In addition to strong similarities in claw morphology, they have similar configuration of the bucco-pharyngeal apparatus and show strong similarities in the structure of the egg shell.

\section{ACKNOWLEDGMENTS}

I would like to thank Dr. A.V. Barabanov, Dr. I.G. Danilov and Dr. A. Voronkov (Zoological Institute, Russian Academy of Sciences, St.-Petersburg) for collecting the material studied here. I am most grateful to Prof. G. Pilato (University of Catania, Italy) for examining and discussing my material, and for sending me slides of $M$. tenuis. I want to thank Dr. H. Dastych (University of Hamburg, Germany) for sending me slides of $M$. ariekammensis and also Prof. R. Bertolani and Dr. R. Guidetti (University of Modena and Reggio Emilia, Italy) for sending me slides of several species of the $M$. tenuis-group. I am very thankful to anonymous reviewers for their corrections of my paper. This work was partially supported by a grant of the "Bioresources" program of the Presidium of the Russian Academy of Sciences.

\section{REFERENCES}

Binda, M.G. \& G. Pilato. 1972. Tardigradi muscicoli di Sicilia. IV Nota. Boll. Accad. Gioenia Sci. Nat. Catania, 3-4: 47-60.

Guidetti, R. \& R. Bertolani. 2001. An evolutionary line of the Macrobiotinae (Tardigrada, Macrobiotidae): Calcarobiotus and related species. Ital. J. Zool., 68: 229-233.

Maucci, W. 1973. Macrobiotus spallanzanii sp. nov. and redescription of Macrobiotus tenuis Binda \& Pilato (Tardigrada, Macrobiotidae). Boll. Zool., 40: 261-267.

Maucci, W. 1987a. A contribution to the knowledge of the North American Tardigrada with emphasis on the fauna of Yellowstone National Park (Wyoming). In: R. Bertolani (Ed.), Biology of Tardigrades. Selected Symposia and Monographs U.Z.I, 1. Mucchi Editore, Modena, Italy: 187-210.

Maucci, W. 1987b. Tardigradi della Mongolia Esterna, con descrizione di Macrobiotus mongolicus sp. nov. Boll. Mus. Civ. St. Nat. Verona, 14: 339-349.

Pilato, G. 1981. Analisi di nuovi caratteri nello studio degli Eutardigradi. Animalia, 8: 51-57.

Tumanov, D. 2005. Two new species of Macrobiotus (Eutardigrada, Macrobiotidae) from Tien Shan (Kirghizia), with notes on Macrobiotus tenuis group. Zootaxa, 1043: 33-46. 